education studies: views of students with special educational needs and disabilities.

https://educationaltechnologyjournal.springeropen.com/articles/10.1186/s4 1239-020-00236-9\#Abs1 [in English].

TeSLA (2020). TeSLA on Vimeo. URL: https://vimeo.com/164100812 [in English] UOC. (2020). The UOC leads European TeSLA project: a system to verify students' identities in examinations and learning activities. URL: https://studies.uoc.edu/en/uoc-leads-tesla-project [in English].

УДК 377.011.3-051

DOI: https://doi.org/10.35387/od.2(20).2021.203-211

Гомеля Ніна Семенівна кандидат педагогічних наук, викладач Київського профресійнопедагогічного фахового коледжу імені Антона Макаренка
Homelia Nina - Candidate of Pedagogic Sciences, Teacher of the Anton Makarenko Kyiv Professional and Pedagogical Applied College

ORCID iD: https://orcid.org/0000-0002-0638-5138

E-mail: enes63@ukr.net

Данькевич Віта Григорівна кандидат педагогічних наук, викладач Київського профресійнопедагогічного фрахового коледжу імені Антона Макаренка
Dankevych Vita - Candidate of Pedagogic Sciences, Teacher of the Anton Makarenko Kyiv Professional and Pedagogical Applied College

ORCID iD: https://orcid.org/0000-0003-1950-7015

E-mail:vitadan76@ukr.net

Штапір Ольга Миколаївна викладач Київського профресійнопедагогічного фрахового коледжу імені Антона Макаренка
Shtapir Olga - Teacher of the Anton Makarenko Kyiv Professional and Pedagogical Applied College

ORCID iD: https://orcid.org/0000-0003-2296-5914

E-mail: olgashtapir@gmail.com

\title{
ІСТОРИКО-ПЕДАГОГІЧНИЙ АСПЕКТ ФОРМУВАННЯ ПІДПРИЄМНИЦЬКОЇ КОМПЕТЕНТНОСТІ МАЙБУТНІХ ПЕДАГОГІВ ПРОФЕСІЙНОГО НАВЧАННЯ
}

Анотація. В оглядовій статті автори здійснюють історикопедагогічний аналіз формування підприємницької компетентності майбутніх педагогів профресійного навчання. Виявлено стан розробленості проблеми 
формування підприємницької компетентності майбутніх педагогів профресійного навчання в теорії та практиці вітчизняної і зарубіжної освіти. Зокрема, розглянуто ідеї поєднання праці з навчанням у педагогічній науці $X X$ століття та деталізовано досвід Антона Макаренка щодо організації трудової діяльності вихованців, яка грунтується на ціннісній основі і сприяє творчій та профресійній реалізації потенціалу особистості.

У cmammi проаналізовано ключові компетентності педагога профресійного навчання та обгрунтовано необхідність формування підприємницької компетентності для педагогічної діяльності і всебічного розвитку особистості майбутніх організаторів професійної підготовки закладів професійно-технічної освіти. Розглянуто теоретичні основи $i$ узагальнено практичний досвід формування підприємницької компетентності загалом та запропоновано напрями фоормування підприємницької компетентності майбутніх педагогів профессійного навчання задля успішної особистісної та професійної самореалізації здобувачів освіти закладів вищої та фрахової передвищої освіти.

Автори переконливо доводять, що вирішення проблеми розвитку підприємливості у підростаючого покоління можливе через впровадження в освітній процес підприємницького змісту як у ході викладання навчальних дисциплін, так і в позаурочний час. 3 цією метою охарактеризовано вибіркову дисципліну «Основи підприємницького успіху», яка спрямована на формування підприємницької компетентності.

Акцентовано увагу на тому, що сформована підприємницька компетентність майбутніх педагогів профресійного навчання стане підгрунтям для їх професійного саморозвитку, усвідомленою потребою в неперервному самовдосконаленні, ставленні до навчання та буде реалізуватись через освітню діяльність, розвиваючи соціально-значимі якості своїх учнів.

Ключові слова: підприємницька компетентність; педагог профресійного навчання; профресійне та особистісне зростання; заклади фахової передвищої освіти.

\title{
Homelia Nina, Dankevych Vita, Shtapir Olga
}

\section{HISTORICAL AND PEDAGOGICAL ASPECT OF ENTREPRENEURIAL COMPETENCE FORMATION AT FUTURE PEDAGOGUES OF PROFESSIONAL TRAINING}

\begin{abstract}
In the review article, the authors carry out a historical and pedagogical analysis of the entrepreneurial competence formation at future pedagogues of professional training. The state of development of the problem of entrepreneurial competence formation at future pedagogues of professional training in the theory and practice of domestic and foreign education is revealed. In particular, the ideas of combining work with teaching in the pedagogical science of the twentieth century are considered, and Anton Makarenko's experience in organizing the students' work, which is based on values and promotes creative and
\end{abstract}


professional realization of personal potential.

The article analyzes the key competencies of pedagogues of professional training and substantiates the need for the entrepreneurial competence formation for teaching activity and comprehensive development of personality of the future organizers of professional training of vocational education institutions. There have been considered the theoretical bases and generalized the practical experience of entrepreneurial competence formation in general; and the directions of entrepreneurial competence formation at future pedagogues of professional training for successful personal and professional self-realization of students of higher and professional pre-higher educational establishments are offered.

The authors are convinced that the solution to the problem of entrepreneurship development at the younger generation is possible through the introduction of entrepreneurial content in the educational process both during the academic disciplines teaching and extracurricular activities. To this purpose, the elective course "Fundamentals of Entrepreneurial Success», which is aimed at the formation of entrepreneurial competence is characterized.

Emphasis is placed on the fact that the formed entrepreneurial competence of future pedagogues of professional training will be the basis for their professional self-development, the perceived need for continuous self-improvement, attitude to learning and will be realized through educational activities with developing socially significant qualities of their students.

Key words: entrepreneurial competence; pedagogue of professional training; professional and personal growth; institutions of professional pre-higher education.

Постановка проблеми, їі актуальність. В умовах світової фрінансової кризи, яка диктує свої умови функціонування і життя в сучасному суспільстві, фрормування економічного мислення, підприємницької компетентності кожного члена суспільства, як профресіоналів, так і майбутніх фрахівців, $є$ однією з провідних задач педагогічної науки і практики, оскільки, з одного боку, ці знання та вміння $є$ необхідними для тверезої оцінки особистого економічного становища та початку ефеетивних дій, спрямованих на його покращення; з другого боку, як суспільне явище, вони можуть бути рушійною силою для подолання результатів економічної кризи українського суспільства в цілому. Для успішної особистісної та професійної самореалізації випускникам закладів вищої та фахової передвищої освіти необхідні такі якості й здібності, які б забезпечили соціальну адаптованість та професійну мобільність, яка має орієнтуватися на сучасний ринок праці.

Тому підготовка майбутніх педагогів професійного навчання повинна включати не лише формування системи знань та вмінь з обраного фаху: дбайливого ставлення до власності, вироблення вміння раціонально використовувати наявні ресурси для задоволення різноманітних потреб; а й розвиток якостей особистості, які можуть і вміють при вирішенні сучасних проблем мислити стратегічно та водночас ситуативно - прагматично, здатних стабільно забезпечувати економічну та соціальну ефективність діяльності різних підприємств в усіх галузях (Майковська, 2017). 
Аналіз актуальних досліджень і публікацій. Питання економічної освіти та економічного виховання учнів досліджені в роботах А. Нісімчук, Л. Куракова, С. Бадмаєва та Д. Березовської. Різні аспекти економічної підготовки майбутніх учителів вивчалися А. Войнаровським, А. Мазурком, І. Сасовою, О. Падалкою, О. Шпаком. Розуміння місця трудового навчання в засвоєнні основ економічних наук учнями основної школи розкрив П. Левін.

Психолого-педагогічні аспекти підприємницької діяльності проаналізовані в наукових дослідженнях В. Андріанової, 3. Гіптерс, І. Демури, О. Зав'ялової, Ю. Пачковского, С. Посохова, В. Шабанової та ін. Стан підготовки молоді до підприємницької діяльності розкрито в науковометодичних працях і монографічних розвідках (М. Бойко, Д. Закатнов, Л. Козачок, С. Мельник, Н. Пасічник, Н. Покатиловський, О. Тополь, О. Семенюк, О. Щербак та ін.).

Окрему групу становлять дослідження, присвячені актуальним питанням формування підприємницької компетентності учнівської молоді (Г. Назаренко, Ю. Кулімова), студентів в Україні (Ю. Баніт, С. Лупаренко) та за кордоном (Н. Ткачова, Ду Цзінсюй), майбутніх учителів (О. Земка, Н. Кінах, В. Кравець, М. Ляшенко, О. Семеног), фахівців економічного профрілю (Г. Матукова) та підприємництва (І. Середіна, С. Стеблюк). Водночас аналіз науково-педагогічних праць засвідчує відсутність фундаментальних досліджень, у яких було б цілісно обґрунтовано теоретичні та практичні засади формування підприємницької компетентності майбутніх педагогів професійного навчання в умовах економіки знань.

Мета статті. На основі цілісного історико-педагогічного аналізу та практики формування підприємницької компетентності студентів у закладах освіти визначити перспективні напрями творчого застосування виявленого досвіду у підготовці майбутніх педагогів професійного навчання.

Виклад основного матеріалу дослідження. Нові економічні умови розвитку України, її інтеграція до Європейського простору зумовили необхідність підготовки населення до участі у здійсненні підприємницької діяльності (Свистун, 2006). В умовах глобалізації проблема підготовки конкурентоспроможного персоналу набула міжнародного значення. Вона $€$ визначальною в діяльності ЮНЕСКО, Європейського фонду освіти та Європейського центру розвитку професійної освіти і навчання CEDEFOР» (Майковська, 2019, с. 19; 51).

Основним орієнтиром для розв'язання цієї проблеми у підготовці педагога професійного навчання є затверджений і введений в дію наказом Міністерства освіти і науки України від 21.11.2019 р. № 1460 Стандарт вищої освіти України (перший (бакалаврський) рівень, галузь знань 01 «Освіта / Педагогіка», спеціальність 015 - «Професійна освіта (за спеціалізаціями)»), який містить перелік компетентностей випускників. Уточнюючи їх зміст необхідно зазначити, що трактування однієї із загальних компетентностей («здатність виявляти ініціативу та 
підприємливість (К 10)»), зобов'язує заклади освіти вводити зміни в їх організаційно-методичну діяльність, що має на меті вміння планувати й управляти проєктами культурної, соціальної або комерційної цінності.

О. Чарушина слушно зауважує, що підприємливість $є$ поєднанням соціального та індивідуального, і це, з одного боку, виражає відмінності й несхожість кожної людини, а з іншого - характеристику такого рівня їі розвитку, досягнути якого може лише соціально-активна особистість (Чарушина, 2006). Відтак профресійна підготовка фрахівців, які відповідають означеним вище характеристикам, вимагає нових підходів до організації освітнього процесу.

Ідея поєднання праці з навчанням як засобу вироблення загальних трудових навичок, формування відповідних моральних якостей, здатності засвоювати економічну інформацію, розуміти базові економічні категорії не була новою у педагогічній науці. Ще на початку XXст. П. Блонський у роботі «Трудова школа» обґрунтовував їх ефективність. Тотожні ідеї відображені у педагогіці В. Лая, в теорії «трудової школи» й громадянського виховання німецького педагога Г. Кершенштейнера. Профресійну підготовку Г. Кершенштейнер пропонував здійснювати в додаткових школах для працюючих підлітків, які закінчили народну школу. Навчальна програма передбачала вивчення загальнотехнічних предметів (знання матеріалів, знарядь та інструментів, креслення, моделювання й практичні тренувальні вправи в шкільних майстернях). Вивчалась також економіка підприємства, взаємовідносини між роботодавцями та робітниками та ін. (Абашкіна, 1998, с. 194-197).

Ефективне поєднання теоретичного i практичного навчання пов'язане з ім'ям видатного педагога А. Макаренка, ідеї якого визначили напрями педагогічного мислення у XX ст. і стали підґрунтям для розвитку інноваційних технологій професійної підготовки в освіті XXI ст. А. Макаренко був упевнений, що будь-яка трудова діяльність повинна ґрунтуватися на ціннісній основі, сприяти формуванню таких здібностей, які б сприяли творчій та професійній реалізації потенціалу особистості.

Відомо, що принципи трудового виховання були закладені видатним педагогом ще у колонії ім. М. Горького, де з перших днів перебування вихованці привчалися до праці. Та найефективніша реалізація ідей А. Макаренка щодо професійного розвитку особистості, формування підприємницьких якостей майбутніх фахівців відбувалася в комуні ім. Ф.Е.Дзержинського, де вихованці мали змогу працювати на сучасному машинному виробництві, що призвело до надзвичайно успішних результатів: комуна перейшла на повний госпрозрахунок і не тільки відмовилася від будь-яких державних дотацій на утримання, але й давала державі щорічно близько 5 млн. крб. прибутку; завдяки госпрозрахунку комунари могли витрачати на рік 200 тисяч карбованців на літні походи, 40 тисяч - на квитки у харківські театри; могли дозволити платити додаткові стипендії своїм випускникам, давати солідне придане для подружнього життя (Ткаченко, 2011).

Таким чином, А. Макаренко теоретично й експериментально довів, 
що трудове виховання й політехнічна освіта $є$ інструментом фрормування гармонійно розвиненої, затребуваної суспільством особистості. А ці якості у сучасному світі вважаються складовими конкурентоспроможності фрахівця на рику праці.

Вивчення зарубіжних наукових джерел щодо фрормування підприємницької компетентності зосередив нашу увагу на китайському досвіді, який складає такі ідеї: проведення протягом століть неоднозначної політики щодо підприємництва, що проявляється, з одного боку, у підтримці підприємницької діяльності та сприянні підготовці молоді до неї, а з іншого боку - в установленні жорсткого контролю й обмежень щодо представників цієї професії; приділення наставниками значної уваги питанню формування в майбутніх підприємців законослухняності й патріотизму; культивування в родинах і школах цінності підприємництва як запоруки гідного життя людини. Пізніше зазначені ідеї отримали подальший розвиток на всіх наступних етапах історії китайського суспільства, причому на кожному з них реалізація зазначених ідей мали свої особливості, зумовлені соціально-політичними та економічними обставинами в країні (Ду Цзінсюй. 2020).

Отже, враховуючи історико-педагогічну складову вітчизняного і зарубіжного досвіду та погоджуючись із дослідницею Ю. Біловою, яка визначає підприємницьку компетентність як інтегральну психологічну якість особистості, що проявляється в мотивованій здатності до творчого пошуку та реалізації нових ідей і дає змогу вирішувати різноманітні проблеми в повсякденному, професійному, соціальному житті, (Білова. 2013) схиляємося до думки, що при формуванні зазначеної компетентності виникають суперечності:

- між наявним економічним рівнем знань майбутніх педагогів професійного навчання i не достатньою обізнаністю їх в області економічного обґрунтування технічних та технологічних особливостей виготовлення виробів та проведення маркетингових досліджень;

- між необхідністю формування підприємницької компетентності в учнів професійних (професійно-технічних) закладів освіти на уроках виробничого навчання і профільно-орієнтованих дисциплін та низьким рівнем знань з основ планування бізнесу та підприємницької діяльності у майбутніх педагогів професійного навчання. А це в свою чергу впливає на те, що майбутній педагог професійного навчання самостійно повинен заповнювати прогалини у своїй економічній підготовці.

Зокрема, за освітньо-професійною програмою підготовки бакалаврів спеціальності 015 - «Професійна освіта (за спеціалізаціями) передбачається вивчення наступних економічних дисциплін: «Основи економічної теорії» та «Економіка та організація виробництва», і цього замало для подальшої ефективної діяльності майбутніх педагогів професійного навчання.

Сьогодення вимагає упровадження в освітній процес інноваційних підходів, ефрективних методів, направлених не тільки і не стільки на засвоєння теоретичних знань та практичних навичок, скільки на розвиток 
мислення, самопізнання, вміння бачити проблеми та вміти творчо їх вирішувати. Київський професійно-педагогічний фаховий коледж імені Антона Макаренка, використовуючи матеріали Транснаціонального проєкту «Підприємництво в освіті і навчанні», увів в освітній процес дисципліну «Основи підприємницького успіху», метою якої $\epsilon$ розвиток ділової активності та особистісних якостей здобувачів освіти. Зокрема таких, як самосвідомість, самооцінка, самопізнання. Надзвичайно важливо, щоб кожна молода людина знала про свої слабкі та сильні сторони, уміла вчитися на власних помилках і, урешті-решт, стала активним та дієвим членом суспільства.

Зміст дисципліни включає теми, які об‘єднані в три модулі: «Психологія особистості», «Комунікація», «Бізнес-планування». Під час вивчення даних тем передбачені такі практичні вправи, як мозковий штурм, робота малими групами, тестування, рольові ігри, вправи на логічне мислення. Наприкінці вивчення дисципліни передбачається недиференційований залік.

Дуальна фрорма здобуття освіти у закладах фахової передвищої освіти $є$ важливим інструментом творення підприємницького успіху у майбутніх педагогів професійного навчання, можливість пов'язання змісту уроку з реальними подіями та сучасною ситуацією на ринку праці. В Україні застосовують дві моделі ДФЗО - модель із інтегрованою практичною підготовкою та із інтегрованою професійною діяльністю. Перша модель передбачає поєднання періодів навчання здобувачів першої вищої чи фахової передвищої освіти в закладі освіти та на підприємстві. Другу модель розроблено для поєднання навчання в ЗВО та на підприємстві для тих, хто вже здобув фахову передвищу або першу вищу освіту, працює на підприємстві та має бажання продовжити навчання за своїм профілем або профілем, визначеним підприємством. Київським професійно-педагогічним фаховим коледжем імені Антона Макаренка першою і другою моделлю дуальної форми здобуття освіти охоплено близько $45 \%$ майбутніх майстрів виробничого навчання та педагогів професійного навчання, що на наше переконання допоможе формуванню підприємницьких позицій та підприємливого способу мислення майбутніх педагогів професійного навчання.

Висновки і перспективи подальших досліджень. Отже, досягнення економічної, історичної, психологічної, соціологічної науки дають підстави говорити про підприємницьку компетентність як особливий тип підприємницької поведінки майбутніх педагогів професійного навчання, для якої характерні такі складові: особлива чутливість до змін і прагнення щось змінити у своєму житті (елемент ініціативи); відповідальність за можливі невдачі та поразки (елемент ризику); упровадження винаходів та інновацій (елемент новаторства); самостійність суджень (елемент свободи); спрямованість на уміння перетворення довкілля, на побудову нових відносин, уміння випереджувати події (елемент активності).

В останні десятиріччя підприємництво та підприємницька освіта в Україні інтенсивно розвиваються, проте в цих царинах існує багато різних 
проблем. Тому подальші дослідження спрямовуватимуться на пошук шляхів підвищення рівня сформованості підприємницької компетентності майбутніх педагогів професійного навчання - представників нової формації сучасних фахівців для України.

\section{Список використаних джерел}

Абашкіна, Н. В. (1998). Професійна підготовка вихованців у навчальних закладах А. Макаренка і Г. Кершенштейна. Педагогіка і психологія, 1, 194-197.

Білова, Ю. А. (2013). Поняття та структура підприємницької компетентності майбутніх фахівців економічного профілю. Оновлення змісту, форм та методів навчання і виховання в закладах освіти, 7, 15-17.

Ду Цзінсюй (2020). Визначення поняття «підприємницька компетентність» у китайській та українській науковій думці (результати порівняльного аналізу). Інноваційна педагогіка, 22 (1), 13-15.

Майковська, В.І. (2017). Проблеми формування підприємницької компетентності в українській освіті. Наукові праці вищого навчального закладу «Донецький національний технічний університет», 1 (20), 73-80

Ткаченко, А. В. (2011). Завод електроінструментів дитячої трудової комуни імені Ф. Е. Дзержинського як середовище професійного розвитку особистості. Педагогіка і психологія проф. освіти, 6, 183-192.

Чарушина, Е. И. (2006). Формирование предприимчивости у старшеклассников в условиях социально-экономического профиля обучения: дис. ... канд. пед. наук: 13.00.02. Кострома.

\section{References (translated and transliterated)}

Abashkina, N.V. (1998). Profesiina pidhotovka vykhovantsiv u navchalnykh zakladakh A. Makarenka i H. Kershenshteina [Professional training of pupils in educational institutions of A. Makarenko and G. Kershenstein]. Pedahohika i psykholohiia - Pedagogy and Psychology, 1, 194-197 [in Ukrainian].

Bilova, Yu. A. (2013). Poniattia ta struktura pidpryiemnytskoi kompetentnosti maibutnikh fakhivtsiv ekonomichnoho profiliu [The concept and structure of entrepreneurial competence of future economic professionals]. Onovlennia zmistu, form ta metodiv navchannia i vykhovannia $v$ zakladakh osvity [Updating the content, forms and methods of teaching and education in educational institutions]. 7, 15-17 [in Ukrainian].

Du Tszinsiui. (2020). Vyznachennia poniattia «pidpryiemnytska kompetentnist»u kytaiskii ta ukrainskii naukovii dumtsi (rezultaty porivnialnoho analizu) [Definition of the concept of «entrepreneurial competence» in Chinese and Ukrainian scientific thought (results of comparative analysis)]. Innovatsiina pedahohika - Innovative pedagogy, 22 (1), 13-15 [in Ukrainian].

Maikovska, V. I. (2017). Problemy formuvannia pidpryiemnytskoi kompetentnosti v ukrainskii osviti [Problems of formation of entrepreneurial competence in Ukrainian education]. Naukovi pratsi vyshchoho navchalnoho zakladu "Donetskyi natsionalnyi tekhnichnyi universytet» - Scientific works of the higher educational institution "Donetsk National Technical University», 1 
(20), 73-80 [in Ukrainian].

Tkachenko, A. V. (2011). Zavod elektroinstrumentiv dytiachoi trudovoi komuny imeni F.E. Dzerzhynskoho yak seredovyshche profesiinoho rozvytku osobystosti [Plant of power tools of the children's labor commune named after FE Dzerzhinsky as an environment of professional development of personality]. Pedahohika i psykholohiia prof. osvity - Pedagogy and psychology prof. Education, 6, 183-192 [in Ukrainian].

Charushyna, E. Y. (2006). Formyrovanye predpryymchyvosty u starsheklassnykov v uslovyiakh sotsyalno-эkonomycheskoho profylia obuchenyia: dys. ... kand. ped. Nauk: 13.00.02 [Formation of entrepreneurship in high school students in the socio-economic profile of education]. Kostroma [in Russian].

УДК 374.72:37.046 (560)

DOI: https://doi.org/10.35387/od.2(20).2021.211-218

Постригач Надія Олегівна -
докторка педагогічних наук,
старший дослідник, старша
наукова співробітниця відділу
зарубіжних систем педагогічної
освіти і освіти дорослих
Інституту педагогічної освіти і
освіти дорослих імені Івана
Зязюна НАПН України

ORCID iD: https://orcid.org/0000-0002-5433-2938

E-mail: unadya1@gmail.com

\begin{abstract}
Postryhach Nadiia - Doctor of Pedagogical Sciences, Senior Researcher at the Department of Foreign Systems of Pedagogical and Adult Education of the Ivan Ziaziun Institute of Pedagogical and Adult Education of the NAES of Ukraine
\end{abstract}

\section{ДІЯЛЬНІСТЬ ЦЕНТРІВ БЕЗПЕРЕРВНОÏ ОСВІТИ У ТУРЕЧЧИНІ}

Анотація. Здійснений контент-аналіз літературних джерел засвідчив, що вітчизняна система безперервної освіти $\epsilon$ інституційно роздрібненою, не має достатніх ознак системності, характеризується відсутністю надійних механізмів стимулювання й недостатньо забезпечена фрінансово. Це зумовлює актуальність дослідження зарубіжного досвіду реалізації системи безперервної освіти, зокрема в Туреччині, що зумовлена потребою розширення їі доступності для всіх верств населення через створення центрів безперервної освіти при університетах.

Автор статті аналізуе особливості діяльності центрів безперервної освіти у Туреччині на базі університетів. Виявлено, що такі центри, спрямовані на досягнення локального розвитку, встановлюють зв'язки між університетами, виробниками знань, ринком та користувачами знань.

З'ясовано, що цільовою групою для реалізації освітньої діяльності центрів безперервної освіти є переважно особи з певним браком освіти, працівники без формальних кваліфрікацій, працівники-іммігранти та сільські 